\title{
The Influence of Institutional and Government Ownership on Firm Performance: Evidence from Kuwait
}

\author{
Mishari Alfaraih ${ }^{1}$, Faisal Alanezi ${ }^{1} \&$ Hesham Almujamed $^{1}$ \\ ${ }^{1}$ Accounting Department, College of Business, the Public Authority for Applied Education and Training, \\ Kuwait \\ Correspondence: Mishari Alfaraih, Accounting Department, College of Business, the Public Authority for \\ Applied Education and Training, Kuwait. E-mail: m@alfaraih.com
}

Received: July 25, 2012

Accepted: August 15, 2012

Online Published: September 3, 2012

doi:10.5539/ibr.v5n10p192

URL: http://dx.doi.org/10.5539/ibr.v5n10p192

\begin{abstract}
Drawing on prior theoretical and empirical research examining corporate governance mechanisms, this study empirically explores the effects of institutional and government ownership on the performance of firms listed on the Kuwait Stock Exchange (KSE). Both a market-based measure (Tobin's Q) and an accounting-based measure (ROA) are used to measures firm performance. Based on a sample of 134 firms listed on the KSE in the year 2010, regression analysis results show a positive relationship between institutional investors and KSE firm performance, suggesting the powerful and influential role institutional investors play as a corporate governance mechanism. In contrast, a negative relationship is observed between government ownership and KSE firm performance, implying worse market performance when government ownership exists. The findings imply that different types of ownership structures have different affects on firm performance. Some ownership structures enhance performance while others worsen performance.
\end{abstract}

Keywords: institutional, government, ownership, firm performance, emerging markets

\section{Introduction}

Corporate governance as a topic has been attracting international concern and debate due to, among other factors, a series of recent corporate failures and collapse of major economic and financial institutions. The need for corporate governance arises from potential conflicts of interest between managers and shareholders due to the separation of the ownership and management functions (Berle \& Means, 1932). Shareholders are interested in maximizing the value of a firm, whereas managers' objectives may also include enhancing personal wealth, job security, and prestige (Mak \& Li, 2001). Brigham (1995) argues that managers of large firms could work just hard enough to keep shareholders' returns at a "reasonable" level and then devote the remainder of their efforts and resources to higher executive salaries or employee benefits. Jensen and Meckling (1976) argue that the interests of the agents (managers) must be aligned with those of the principals (shareholders) in order to solve the principal-agent (agency) problem. Shleifer and Vishny (1997) argue that corporate governance can mitigate the agency problem and provide assurance that managers' activities concentrate on maximizing the value of a firm. Denis and McConnell (2003) define corporate governance as the set of mechanisms that induce the self-interested controllers of a company (managers) to make decisions that maximize the value of the firm for its owners (shareholders). To limit agency conflicts and mitigate agency costs, the theoretical literature on corporate governance proposes numerous internal and external governance mechanisms. These include the board of directors, debt financing, ownership structures, and the market for corporate control (Haniffa \& Hudaib, 2006). In their survey of corporate governance around the world, Shleifer and Vishny (1997) note that the subject of corporate governance is of enormous practical importance worldwide as there is a great deal of disagreement regarding the effectiveness of various corporate governance mechanisms. To this end, several empirical studies on corporate governance have examined the role of various governance mechanisms on firm performance, assuming firm value is an outcome of these mechanisms. Some studies explore the relationship between firm performance and ownership (e.g., Haniffa \& Hudaib, 2006; Rose, 2007; Gurbuz et al., 2010; Najid \& Rahman, 2011). Others (e.g., Tian \& Chung-Ming, 2001; Nguyen \& Faff, 2007; Christensen et al., 2010) examine the relationship between board of directors structure variables and firm performance. In addition, some studies assess the influence of dividend policy (e.g., Kowalewski et al., 2008) and audit quality (e.g., Aljifri \& Moustafa, 2007). 
The above review of the theoretical literature on corporate governance mechanisms demonstrates the importance of these mechanisms in limiting agency conflicts and mitigating agency costs. However, many empirical studies that examine this issue have been conducted in countries with highly developed markets. Shleifer and Vishny (1997) argue that in less developed markets, effective corporate governance mechanisms are practically nonexistent. In this context, the objective of this study is to explore the effects of institutional and government ownership on the performance of firms listed on the Kuwait Stock Exchange (KSE). Understanding the role of institutional and government ownership on firm performance allows an assessment of their current effectiveness as governance mechanisms as well as opportunities for potential improvements.

Using a sample of 134 firms listed on the KSE in 2010, this study examines how firm performance is related to institutional and government ownership. A forward-looking market-based measure (Tobin's Q) and an historical accounting-based measure (return on assets or ROA) are used to measure firm performance. Based on these markets and accounting measures, a significant positive relationship between institutional ownership and firm performance was detected. In contrast, a significant negative relationship between government ownership and firm performance was observed. The results are robust when controlled for board size, role duality, audit quality, dividend payouts, firm size, leverage, and industry category. The results provide partial support for the theoretical literature on corporate governance that concerns the effects of governance mechanisms on firm performance. Empirically, the results help clarify how effective institutional and government ownership as corporate governance mechanisms are in the Kuwaiti context in which highly concentrated ownership is predominant as the Kuwaiti listed companies are owned and controlled by few major shareholders.

The remainder of the paper is organized as follows: Section 2 briefly reviews ownership structures in Kuwait business environment. Section 3 discusses the theoretical and empirical literature on institutional and government ownership as corporate governance mechanisms and posits the hypotheses to be tested. Section 4 describes the data and methodological approach used. Section 5 discusses the empirical results and research findings. Section 6 presents the conclusions.

\section{Ownership Structures in Kuwait Business Environment}

Kuwaiti firms listed on the KSE have different ownership structures (government, dominant family, individuals, institutional investors). Unlike Anglo-American practice, ownership in Kuwait generally is highly concentrated. Statistics showed that most the Kuwaiti listed companies are owned and controlled by few major shareholders. These shareholders are government and its agencies, institutional investors, dominant families and individuals. According to KSE regulations, stockholders of listed firms are required to disclose immediately to the KSE if their holding reaches (directly or indirectly) 5 per cent of company's capital. Similarly, listed firms should disclose immediately the names of shareholders whose ownership interest reaches 5 per cent of its total shares.

Al Mutairi (2011) conducts a study in 2009 on ownership structure in Kuwait. The study shows that the Kuwaiti government holds substantial equity ownership in the manufacturing $(11.5 \%)$, services $(11.22 \%)$ and investments (10.75\%) industries. While it holds a small equity ownership in insurance (7.06\%) and food (8.57\%) industries. Institutional investors hold a large stake in services (17.23\%), banking (28.70\%) and manufacturing $(28.05 \%)$ industries. Dominant families hold the largest shares in banking $(27.10 \%)$ and manufacturing $(16.07 \%)$ industries. While individuals have the substantial equity in investments $(58.00 \%)$, food $(58.01 \%)$, insurance $(57.05 \%)$ and real estate $(55.15 \%)$ industries.

\section{Theoretical Background, Prior Studies, and Hypotheses Development}

This section discusses the theoretical background of the relationship between firm performance and institutional and government ownership. Based on a review of the literature, two research hypotheses are developed regarding the relationship between firm performances and ownership structure.

\subsection{Institutional Ownership (INST)}

Agency theory concerns the behavior of principals (shareholders) and agents (managers) in light of the separation between ownership and firm control. The theory explains problems that arise when shareholders rely on managers to provide services on their behalf, due to the separation of ownership and control (Jensen and Meckling, 1976). If parties act in self-interest, the conflicts of interest between shareholders and managers increases. Due to these conflicts, agency costs arise.

It is widely argued that institutional investors are an important corporate governance mechanism that improves firm performance, as institutional investors have both the ability and the incentive to monitor and discipline corporate managers (Aljifri \& Moustafa, 2007; Ping \& Wing, 2011). Rose (2007) justifies the effectiveness of institutional investors as a corporate governance tool based on the grounds that institutional investors might discipline management, because the free-rider problem associated with dispersed ownership is alleviated. In 
addition, due to institutional investors' power to influence board decisions, absorb the cost of effective monitoring, and engage in active ownership, their presence might positively affect firm performance (Shleifer \& Vishny, 1997; Rose, 2007). However, Duggal and Millar (1999) challenge the ability of institutional investors to effectively monitor management and enhance firm performance. Similarly, Gorton and Kahl (1999) argue that ownership by institutional investors does not necessarily enhance firm performance because institutional investors may provide an insignificant monitoring role due to their own internal agency conflicts.

Although several prior empirical studies have explored the relationship between institutional ownership and firm performance using market and accounting performance measures, the nature of this relationship remains unclear. Some studies have found a positive and significant influence for institutional ownership on firm performance (e.g., Gurbuz et al., 2010; Jaafar \& El Shawa, 2009), while others have found the opposite (e.g., Haniffa \& Hudaib, 2006; Rose, 2007). Because institutional investors are considered an increasingly important control mechanism affecting corporate governance worldwide - one that has the potential to influence management activities and firm performance directly through their ownership and indirectly through their ability to trade their shares (Gillan \& Starks, 2003) - this study uses institutional ownership as a proxy for a corporate governance mechanism of firms. Given the above, a positive influence for institutional ownership on firm performance is expected. This leads to hypothesis 1 :

\section{H1: Institutional ownership is positively associated with firm performance.}

\subsection{Government Ownership (GOV)}

The theoretical literature pertaining to the influence of government ownership on firm performance offers a broad spectrum of potential effects of government ownership. Generally, these studies contend that privately owned firms are more efficient and more profitable than otherwise-comparable state-owned firms in competitive markets (Megginson \& Netter, 2001). Similarly, Najid and Abdul Rahman (2011) claim that state-owned firms generally lack sufficient entrepreneurial drive and tend to be politically rather than commercially motivated, which leads to a poor financial performance. Mak and $\mathrm{Li}$ (2001) argue that government tends to be less active in monitoring its investments; they claim the weaker accountability and monitoring of state-owned firms' financial performance, as well as easier access to financing, are likely to reduce the incentives of such firms to adopt strong governance mechanisms. However, some researchers posit that if government has dominate ownership in a firm, then government may have an incentive to monitor management closely and effectively, which reduces the agency costs for other shareholders and increases the firm's profitability (Bos, 1991). Similarly, Eng and Mak (2003) argue that state-owned firms tend to mitigate the problem of asymmetric information that results from imperfect information about the value of the firms given to investors and that such firms are also generally able to gain easier access to different sources of financing as compared with other firms. In addition, state-owned firms may face less pressure to comply with financial reporting regulations, which might motivate management to select accounting choices that improve firms' performance (Aljifri \& Moustafa, 2007).

The findings of empirical studies regarding the influence of government ownership on firm performance present mixed results. For example, Aljifri and Moustafa (2007) find that government ownership has a positive and significant impact on the United Arab Emirates (UAE) firm performance. Similarly, Najid and Rahman (2011) find that government ownership has a positive, significant influence on the performance of Malaysian firms. In addition, Ang and Ding (2006) show that government-linked firms in Singapore have higher valuations as well as better corporate governance compared with nongovernment-linked firms. In contrast, in Chinese firms $\mathrm{Xu}$ and Wang (1999) find a negative relationship between firm performance and sizeable government ownership. Generally, empirical studies find that firm performance tends to benefit from some level of government ownership. In Kuwait, the government owns an interest in many listed firms. Such firms are more likely to enjoy the benefits associated with government ownership, such as close and effective monitoring, a reduction in agency cost, and easier access to financing. Therefore, it is reasonable to assume that the performance of KSE-listed firms will be positively affected by government ownership. This leads to hypothesis 2 :

\section{H2: Government ownership is positively associated with firm performance.}

\subsection{Control Variables}

The literature identifies certain variables that may influence either corporate governance mechanisms or firm performance. Hence, it is important to control and isolate the potential effects of these variables on corporate governance and firm performance. Following the literature, board size (Christensen et al., 2010; Nguyen \& Faff, 2007), role duality (Haniffa \& Hudaib, 2006), audit quality (Aljifri \& Moustafa, 2007), dividend payouts (Aljifri \& Moustafa, 2007), firm size (Christensen et al., 2010; Gurbuz et al., 2010; Haniffa \& Hudaib, 2006), firm leverage (Ibrahim \& Samad, 2011; Najid \& Abdul Rahman, 2011; Christensen et al., 2010), and industry 
categories (Rose, 2007; Haniffa \& Hudaib, 2006) are used in this study as control variables to capture their impact on corporate governance mechanisms or firm performance.

\section{Data and Methodology}

\subsection{Data}

The purpose of this study is to explore the effects of institutional and government ownership on the performance of firms listed on KSE in the year 2010. Consistent with prior literature, due to their financial characteristics, 67 financial firms were excluded from the sample. The final sample comprises the remaining 134 nonfinancial firms. All data required to investigate the influence of institutional and government ownership on the performance has been collected from the annual reports of KSE-listed firms. In addition, data about ownership, market values, board of director characteristics, and industry classification were obtained from the official website of Kuwait Stock Exchange (http://www.kse.com.kw).

\subsection{Measurement of Firm Performance}

In this study, a forward-looking market-based measure and an historical accounting-based measure are used as proxies to evaluate firms' financial performance. Tobin's Q, which is computed as the ratio of the market capitalization plus the total debt divided by the total assets of the firm, is a popular market-based measure that is widely used as a proxy for firm performance when studying the relationship between firm performance and corporate governance (Dybvig \& Warachka, 2011). Tobin's Q as a market-based measure of firm performance is consistent with the efficient market hypothesis in which the market valuation of a firm measures the use of existing assets and future growth potential (Christensen et al., 2010). In addition, return on assets (ROA), which is the ratio of the net income divided by the total assets, is used as an accounting-based measure. Core et al., (2006) argue that ROA is a preferred proxy for firm performance because it is not affected by leverage, extraordinary items, and other discretionary items. In addition, ROA has more desirable distributional properties than the return on equity. Tobin's Q and ROA have been widely used in examining the relationship between firm performance and corporate governance (see Aljifri \& Mohamed Moustafa, 2007; Rose, 2007; Christensen et al., 2010; Ibrahim \& Samad, 2011).

\subsection{Control Variables and the Measurement of Corporate Governance}

To investigate the influence of institutional and government ownership on firm performance, institutional and government ownership levels are used as independent variables, board size, role duality, audit quality, dividend policy, firm size, firm leverage, and industry categories are used as control variables to capture their influence on corporate governance or firm performance. Table 1 provides the definition and measurement of the variables used in this study.

Table 1. Definition and Measurement of Variables Used in the Study

\begin{tabular}{|c|c|c|}
\hline Variable & Acronym & Measurement \\
\hline \multicolumn{3}{|l|}{ Dependent Variables: } \\
\hline Tobin's Q & $T Q$ & Ratio of the market value of equity plus the total debt divided by the total asset of the firm \\
\hline Return on Assets & ROA & Ratio of the net income divided by the total assets of the firm \\
\hline \multicolumn{3}{|l|}{ Independent Variables: } \\
\hline Institutional Ownership & INST & $\begin{array}{l}\text { Proportion of the ordinary shares held by institutional investors that own at least } 5 \% \text { of the } \\
\text { firm shares to the total shares outstanding of the firm }\end{array}$ \\
\hline Government Ownership & GOV & $\begin{array}{l}\text { Proportion of the ordinary shares held by government that owns at least } 5 \% \text { of the firm } \\
\text { shares to the total shares outstanding of the firm }\end{array}$ \\
\hline Board Size & BSIZE & Number of directors on the board of the firm \\
\hline \multicolumn{3}{|l|}{ Control Variables: } \\
\hline Role Duality & DUAL & $\begin{array}{l}\text { A dummy variable that equals } 1 \text { if the } \mathrm{CEO} \text { of the firm is also the chairman of the board, and } \\
0 \text { otherwise }\end{array}$ \\
\hline Audit Type & AUDIT & $\begin{array}{l}\text { A dummy variable that equals } 1 \text { if a Big- } 4 \text { auditing firms audits the firm's financial } \\
\text { statements, and } 0 \text { otherwise }\end{array}$ \\
\hline Dividend Payout & $D P$ & Dividend-payout ratio: the ratio of the dividends per share to the earnings per share \\
\hline Firm Size & SIZE & The natural logarithm of total assets \\
\hline Firm Leverage & LEVERAGE & The ratio of total debt to total assets \\
\hline \multirow[t]{2}{*}{ Industry Categories } & IND_INDUS & A dummy variable that equals 1 for firms in the industrial category, and 0 otherwise \\
\hline & IND_SERV & $\begin{array}{l}\text { A dummy variable that equals } 1 \text { for firms in the service category, and } 0 \text { otherwise (the } \\
\text { omitted industry category when all categories are } 0 \text { is the Real Estate category) }\end{array}$ \\
\hline
\end{tabular}




\subsection{Regression Models}

Consistent with previous empirical studies that examine the relationship between firm performance and various corporate governance mechanisms, two multivariate regression models are developed and used as follows:

Model 1:

$$
\begin{aligned}
& T Q=\beta_{0}+\beta_{1} I N S T+\beta_{2} G O V+\beta_{3} B S I Z E+\beta_{4} D U A L+\beta_{5} A U D I T+\beta_{6} D P+ \\
& \beta_{7} S I Z E+\beta_{8} L E V E R A G E+\beta_{9} I N D_{-} I N D U S_{i}+\beta_{10} I N D_{-} S E R V_{i}+\varepsilon_{i}
\end{aligned}
$$

Model 2:

$$
\begin{aligned}
& R O A=\beta_{0}+\beta_{1} I N S T+\beta_{2} G O V+\beta_{3} B S I Z E+\beta_{4} D U A L+\beta_{5} A U D I T+\beta_{6} D P+ \\
& \beta_{7} S I Z E+\beta_{8} L E V E R A G E+\beta_{9} I N D_{-} \text {INDUS }{ }_{i}+\beta_{10} I N D{ }_{-} S E R V i+\varepsilon_{i}
\end{aligned}
$$

\section{Results}

\subsection{Descriptive Statistics}

Table 2 presents descriptive statistics for all variables used in this study. Panel A of Table 2 shows descriptive statistics for all continuous variables, while Panel B presents descriptive statistics for dummy variables. Panel A of Table 2 shows that the mean for Tobin's Q, which is a market-based performance measure, is 1.8, ranging from 0.40 to 4.41 . For the accounting-based performance measure, Panel A shows that the mean of ROA is 0.03 , ranging from -0.20 to 0.31 . In addition, Panel A shows that the mean percentage of institutional investors that own at least $5 \%$ of the firm shares is $55 \%$, suggesting concentrated institutional ownership in most KSE firms in 2010. In contrast to institutional ownership, the mean percentage of shares held by the government is only $3 \%$. Furthermore, the descriptive statistics show that the board sizes range from 3 to 10 , with a mean of 5.80. In addition, the dividend-payout ratio has a mean of 0.15 , ranging from 0.00 to 1.29 . Firm size varied significantly, ranging from KD 3.41 million to KD 3709.94 million, with a mean of KD 171.85 million. Due to the variation from normality, the non-normality was corrected with a natural logarithm transformation.

Table 2. Descriptive Statistics of Variables

\begin{tabular}{lllll}
\hline Panel A: & & & & \\
\hline Variable & Mean & Std. Deviation & Minimum & Maximum \\
\hline Tobin's Q & 1.80 & 0.93 & 0.40 & 4.41 \\
Return on Assets & 0.03 & 0.07 & -0.20 & 0.31 \\
Institutional Ownership & 0.55 & 0.23 & 0.00 & 0.96 \\
Government Ownership & 0.03 & 0.09 & 0.00 & 0.69 \\
Board Size & 5.80 & 1.45 & 3 & 10 \\
Dividend Payout & 0.15 & 0.30 & 0.00 & 1.29 \\
Firm Size & 11.17 & 1.28 & 8.13 & 15.13 \\
Firm Leverage & 0.41 & 0.22 & 0.01 & 0.91 \\
\hline Panel B: & & & & \\
\hline Variable & & Yes & Percentage & \\
\hline Role Duality & & 60 & 44.78 & \\
Audit Type - Big-4 & & 61 & 45.52 & \\
Industrial Category & 34 & 44.37 & \\
Service Category & & 60 & 29.85 & \\
Real Estate Category & 40 & & \\
\hline
\end{tabular}

Note: $\mathrm{N}=134$.

The results presented in Panel B of Table 2 indicate that 60 firms have CEO duality, while 76 firms have no CEO duality. The variation among firms concerning role duality could be attributed to the fact that in the Kuwaiti setting, KSE-listed firms are not legally required to separate the roles of chairman and managing director (Alanezi, 2011). In addition, Panel B shows that about $45 \%$ of KSE-listed firms were audited by Big-4 auditing firms.

The Pearson correlations among the independent variables are presented in Table 3. The results show that no pair-wise correlation coefficient exceeds 0.8 , suggesting that multicollinearity is not likely to be a significant problem in interpreting the multiple regression results (Gujarati, 2003; Kennedy, 2003). Variance inflation factors (VIF) were also examined and found to be well within acceptable limits. 
Table 3. Bivariate Correlations among the Variables

\begin{tabular}{llllll}
\hline Independent Variable & Institutional Ownership & Government Ownership & Board Size & Dividend Payout & Firm Size \\
\hline Government Ownership & 0.17 & & & & \\
Board Size & $-0.17^{*}$ & $0.23^{* *}$ & & & \\
Dividend Payout & -0.03 & $0.34^{* *}$ & $0.28^{* *}$ & & \\
Firm Size & $-0.32^{* *}$ & 0.07 & 0.14 & 0.08 & \\
Firm Leverage & -0.11 & -0.09 & $0.36^{* *}$ & -0.13 & $0.48^{* *}$ \\
\hline
\end{tabular}

Note: * ** Correlation is significant at $\leq 0.05$ and 0.01 levels, respectively (2-tailed).

\subsection{Regression Results}

\section{Market-based performance measure}

Panel A of Table 4 provides the regression analysis results based on the market measure, Tobin's Q. It is evident that the ownership structure and corporate governance variables in combination are highly significant in explaining the variation in market performance $(F=7.518, p<0.01)$. The adjusted $R^{2}$ indicates that the ownership structure and corporate governance variables considered in this study explain $34 \%$ of the variations in market performance. Hypothesis 1 predicts that there is a positive influence of institutional ownership on firm performance. Table 4 shows this to be the case $(p<0.01)$. Thus, the result suggests that the existence of institutional investors is associated with better market performance. This result is consistent with the notion of Ping and Wing (2011) and Rose (2007) that the existence of institutional investors might discipline management. In addition, this result supports the argument that due to their power to influence board decisions, absorb the cost of effective monitoring, and engage in active ownership, the presence of institutional investors might positively affect firm performance (Shleifer \& Vishny, 1997). This finding is consistent with those of similar studies in other jurisdictions (e.g., Gurbuz et al., 2010; Jaafar \& El Shawa, 2009).

Hypothesis 2 predicts that firm performance will be positively impacted by government ownership. Contrary to expectation, Table 4 shows that the Government Ownership coefficient, although significant $(p<0.05)$, is negatively associated with market performance, implying worse market performance when government ownership exists. It was predicted that firms would enjoy benefits associated with government ownership, such as close and effective monitoring, reduction in agency costs, and easier access to financing. However, this does not seem to be the case for firms that are listed with the KSE. Although this result rejects hypothesis 2, it provides support for the argument of Najid and Abdul Rahman (2011) that government generally lacks sufficient entrepreneurial drive and tends to be politically rather than commercially motivated, which leads firms to a poor financial performance.

Table 4. Multivariate Regression Analysis Results

\begin{tabular}{|c|c|c|c|c|}
\hline \multicolumn{5}{|c|}{ Explaining Corporate Governance Based on Market and Accounting Performance Measures } \\
\hline \multirow[b]{2}{*}{ Variable } & \multicolumn{2}{|c|}{$\begin{array}{l}\text { Panel A: } \\
\text { Market Performance Measures } \\
\text { Tobin's Q }\end{array}$} & \multicolumn{2}{|c|}{$\begin{array}{l}\text { Panel B: } \\
\text { Accounting Performance Measure } \\
\text { Return on Assets }\end{array}$} \\
\hline & Coefficient & t-statistic & Coefficient & t-statistic \\
\hline Intercept & -0.343 & -0.403 & -0.863 & $-3.286+++$ \\
\hline Institutional Ownership & 0.018 & $2.641 * * *$ & 0.003 & $2.365^{* * *}$ \\
\hline Government Ownership & -0.022 & $-2.355^{* *}$ & -0.002 & -0.883 \\
\hline Board Size & 0.057 & 0.964 & 0.025 & 1.161 \\
\hline Role Duality & 0.048 & 0.311 & -0.043 & -0.987 \\
\hline Audit Type & 0.155 & 1.004 & -0.004 & -0.807 \\
\hline Dividend Payout & 0.010 & $2.207^{* *}$ & 0.001 & $1.528^{*}$ \\
\hline Firm Size & 0.012 & 0.160 & 0.058 & $2.535^{* * *}$ \\
\hline Firm Leverage & -0.553 & $-1.345^{*}$ & -0.393 & $-3.102 * * *$ \\
\hline Industrial Category & 0.670 & $3.156+++$ & 0.135 & $2.068++$ \\
\hline Service Category & 0.374 & $1.968+$ & 0.124 & $2.115++$ \\
\hline \multirow[t]{2}{*}{$\mathbf{N}$} & $\mathbf{R}^{2}$ & F-statistic & $\mathbf{R}^{2}$ & $F$-statistic \\
\hline & 0.391 & 7.518 & 0.218 & 3.257 \\
\hline \multirow[t]{2}{*}{134} & Adj. $R^{2}$ & p-value (F-stat.) & Adj. $R^{2}$ & p-value (F-stat.) \\
\hline & 0.339 & 0.000 & 0.151 & 0.000 \\
\hline
\end{tabular}

Note: * **,*** significant at the $0.10,0.05$, and 0.01 levels respectively (one-tailed).,,++++++ significant at the $0.10,0.05$, and 0.01 levels respectively (two-tailed). 
Panel B of Table 4 provides the regression analysis results based on the accounting-based measure. Similar to the results obtained from the market-based measure model, these results document the significant affect of institutional ownership $(p<0.01)$ on firm performance. Similar to but weaker than the result based on the market measure, government ownership was found to be negatively, but insignificantly, associated with firm performance.

For control variables, the results show that the estimated coefficients for Board Size, Role Duality and Audit Quality are insignificant based on both market and accounting measures. The estimated coefficients for Dividend Payout are positive and significant based on both measures. Firm Size are positive and statistically significant based on the accounting measure, but not the market measure. The estimated coefficients for Leverage are negative and significant based on both market and accounting measures. The findings indicate that the coefficient estimates of all the industry categories are significant.

\section{Conclusions}

The review of the theoretical and empirical literature on corporate governance mechanisms demonstrates the importance of governance mechanisms in limiting agency conflicts and mitigating agency costs. In this context, the objective of this study is to explore the effects of institutional and government ownership on the performance of firms listed on the KSE. A market-based measure (Tobin's Q) and an accounting-based measure (ROA) are used to assess firm performance. Based on a sample of 134 firms listed on the KSE in 2010, the results of regression analysis show a positive relationship between institutional investors and KSE firm performance, suggesting the powerful and influential role that institutional investors play as a corporate governance mechanism. In contrast, the results show a negative relationship between government ownership and KSE firm performance, implying a worse market performance for firms when government ownership exists and supporting the notion that government generally lacks sufficient entrepreneurial drive and tends to be politically rather than commercially motivated. In addition, the results show a positive relationship between dividend payouts and firm performance, implying that firm performance tends to be better with higher dividend payouts. An insignificant relationship was observed between board size, role duality, and audit quality and KSE firm performance, suggesting the weakness of these corporate governance mechanisms in influencing firm performance. These results are robust when controlling for firm size, leverage, and industry category. The results of this study provide partial support for the theoretical literature on corporate governance concerning the effects of governance mechanisms on firm performance. In addition, it contributes to the empirical literature by highlighting how effective some corporate governance mechanisms are in an emerging market in which highly concentrated ownership is predominant.

The study findings have important implications. The findings imply that different types of ownership structures have different affects on firm performance. Some ownership structures enhance performance while others worsen performance. Finding a negative relationship between government ownership and firm performance raises serious questions about the effectiveness of government in monitoring its own firms. One limitation of this study could be attributed to the proxies used to measure firm performance as they may fail to capture the role of some corporate governance mechanisms, such as board structure variables. In addition, there is always the possibility of omitting other governance mechanisms that would assist in explaining variations in firm performance. Future research could examine additional governance mechanisms. Due to data limitations, the results of this study are based on data from a one-year period. Future research could investigate the change in the relationship between governance mechanisms and firm performance.

\section{Acknowledgement}

This work was supported by the Public Authority for Applied Education \& Training - Kuwait/Research Grant no. BS-11-10.

\section{References}

Afshan, N., Chhetri, P., \& Pradhan, S. (2011). Board, Ownership Structure \& Pay and Firm Performance: A Literature Review. IUP Journal of Corporate Governance, 10(2), 82-92.

Al Mutairi, M. (2011). Corporate Finance Decisions, Governance, Environmental Concerns and Performance in Emerging Markets: the Case study of Kuwait. (Unpublished PhD Thesis). University of Wollongong, Australia.

Alanezi, F. (2011). Composition of Corporate Board of Directors and Voluntary Disclosure in the Annual Reports : The Case of Kuwait. Arab Journal of Administrative Sciences, 18(1), 135-163. 
Aljifri, K., \& Moustafa, M. (2007). The Impact of Corporate Governance Mechanisms on the Performance of UAE Firms: An Empirical Analysis. Journal of Economic \& Administrative Sciences, 23(2), 71-93. http://dx.doi.org/10.1108/10264116200700008

Berle, A. A., \& Means, G. C. (1932). The modern corporation and private property. New York: Macmillan.

Bos, D. (1991). Privatization: A Theoretical Treatment. Oxford: Clarendon Press.

Brigham, E. F. (1995). Fundamentals of Financial Management (7th ed.). Orlando, Florida: Dryden Press.

Christensen, J., Kent, P., \& Stewart, J. (2010). Corporate Governance and Company Performance in Australia. Australian Accounting Review, 20(4), 372-386. http://dx.doi.org/10.1111/j.1835-2561.2010.00108.x

Committee, C. (1992). Code of Best Practice: Report of the Committee on the Financial Aspects of Corporate Governance. London, UK: Gee and Co, Ltd.

Core, J. E., Guay, W. R., \& Rusticus, T. O. (2006). Does Weak Governance Cause Weak Stock Returns? An Examination of Firm Operating Performance and Investors' Expectations. Journal of Finance, 61(2), 655-687. http://dx.doi.org/10.1111/j.1540-6261.2006.00851.x

Dahya, J., Lonie, A. A., \& Power, D. M. (1996). The Case for Separating the Roles of Chairman and CEO: An Analysis of Stock Market and Accounting Data. Corporate Governance: An International Review, 4(2), 71-77. http://dx.doi.org/10.1111/j.1467-8683.1996.tb00136.x

Dalton, D. R., Daily, C. M., Ellstrand, A. E., \& Johnson, J. L. (1998). Meta-Analytic Reviews of Board Composition, Leadership Structure, and Financial Performance. Strategic Management Journal 19(3), 269-269. http://dx.doi.org/10.1002/(SICI)1097-0266(199803)19:3<269::AID-SMJ950>3.3.CO;2-B

DeAngelo, L. (1981). Auditor Size and Audit Quality. Journal of Accounting and Economics, 3(3), 183-199. http://dx.doi.org/10.1016/0165-4101(81)90002-1

Denis, D. K., \& McConnell, J. J. (2003). International corporate governance. Journal of Financial and Quantitative Analysis, 38(1), 1-36. http://dx.doi.org/10.2307/4126762

Duggal, R., \& Millar, J. (1999). Institutional ownership and firm performance: The case of bidder returns. Journal of Corporate Finance, 5(2), 103-117. http://dx.doi.org/10.1016/S0929-1199(98)00018-2

Dybvig, P., \& Warachka, M. (2011). Tobin's Q Does Not Measure Performance: Theory, Empirics, and Alternative Measures. Available at SSRN: http://ssrn.com/abstract=1562444.

Eng, L. L., \& Mak, Y. T. (2003). Corporate governance and voluntary disclosure. Journal of Accounting and Public Policy, 22(4), 325-345. http://dx.doi.org/10.1016/S0278-4254(03)00037-1

Fama, E. F., \& Jensen, M. C. (1983). Separation of Ownership and Control. Journal of Law and Economics, 26(2), 301-301. http://dx.doi.org/10.1086/467037

Gillan, S. L., \& Starks, L. T. (2003). Corporate Governance, Corporate Ownership, and the Role of Institutional Investors: A Global Perspective. Journal of Applied Finance, 13(2), 4-22.

Gorton, G., \& Kahl, M. (1999). Blockholder Identity, Equity Ownership Structures, and Hostile Takeovers. NBER Working Paper Series, No. w7123. Available at SSRN: http://ssrn.com/abstract=165132.

Gujarati, D. N. (2003). Basic Econometrics (3rd ed.). New Yourk: McGraw-Hill.

Gürbüz, A. O., Aybars, A., \& Kutlu, Ö. (2010). Corporate Governance and Financial Performance with a Perspective on Institutional Ownership: Empirical Evidence from Turkey. Journal of Applied Management Accounting Research, 8(2), 21-37.

Haniffa, R., \& Hudaib, M. (2006). Corporate Governance Structure and Performance of Malaysian Listed Companies. Journal of Business Finance and Accounting, 33(7-8), 1034-1062. http://dx.doi.org/10.1111/j.1468-5957.2006.00594.x

Haniffa, R. M., \& Cooke, T. E. (2002). Culture, corporate governance and disclousure in Malaysian corporations. Abacus, 38(3), 317. http://dx.doi.org/10.1111/1467-6281.00112

Ibrahim, H., \& Samad, F. A. (2011). Corporate Governance Mechanisms and Performance of Public-Listed Family-Ownership in Malaysia. International Journal of Economics and Finance, 3(1), 105-115.

Jaafar, A., \& El-Shawa, M. (2009). Ownership concentration, board characteristics and performance: evidence from Jordan. Research in Accounting in Emerging Economies, 9, 73-95. 
Jensen, M., \& Meckling, W. (1976). Theory of the Firm: Managerial Behavior, Agency Costs and Ownership Structure. Journal of Financial http://dx.doi.org/10.1016/0304-405X(76)90026-X

Jensen, M. C. (1986). Agency Costs of Free Cash Flow, Corporate Finance, and Takeovers. The American Economic Review, 76(2), 323-323.

Jensen, M. C. (1993). The modern idustrial revolution, exit, and the failure of internal control systems. The Journal of Finance, 48(3), 831-80. http://dx.doi.org/10.1111/j.1540-6261.1993.tb04022.x

Jiraporn, P., Kim, J.-C., \& Kim, Y. S. (2011). Dividend Payouts and Corporate Governance Quality: An $\begin{array}{llll}\text { Empirical Investigation. } & \text { Financial 251-279. }\end{array}$ http://dx.doi.org/10.1111/j.1540-6288.2011.00299.x

Kennedy, P. (2003). A Guide to Econometrics (5th ed). Cambridge, Massachusetts: MIT Press.

Kowalewski, O., Stetsyuk, I., \& Talavera, O. (2008). Does Corporate Governance Determine Dividend Payouts in Poland? Post-Communist Economies, 20(2), 203-218. http://dx.doi.org/10.1080/14631370802018973

Loderer, C., \& Peyer, U. (2002). Board Overlap, Seat Accumulation and Share Prices. European Financial Management, 8(2), 165-192. http://dx.doi.org/10.1111/1468-036X.00183

Mak, Y. T., \& Li, Y. (2001). Determinants of Corporate Ownership and Board Structure: Evidence from Singapore. Journal of Corporate Finance, 7(3), 235-256. http://dx.doi.org/10.1016/S0929-1199(01)00021-9

Malone, D., Fries, C., \& Jones, T. (1993). An empirical investigation of the extent of corporate financial disclosure in the oil and gas industry. Journal of Accounting, Auditing \& Finance, 8(3), 249.

Megginson, W. L., \& Netter, J. M. (2001). From State to Market: A Survey of Empirical Studies on Privatization. Journal of Economic Literature, 39(2), 321-389. http://dx.doi.org/10.1257/jel.39.2.321

Monks, R., \& Minow, N. (2000). Corporate Governance (2nd ed.). Blackwell Publishing Co.

Najid, N., \& Abdul Rahman, R. (2011). Government Ownership and Performance of Malaysian. Government-Linked Companies. International Research Journal of Finance and Economics, (61), 42-56.

Nguyen, H., \& Faff, R. (2007). Impact of board size and board diversity on firm value: Australian evidence. Corporate ownership and control, 4(2), 24-32. http://dx.doi.org/10.1007/s10997-007-9038-1

Ojo, M. (2009). The Role of External Auditors in Corporate Governance: Agency Problems and the Management of Risk. Available at SSRN: http://ssrn.com/abstract=1427899.

Ping, Z., \& Wing, C. (2011). Corporate Governance: A Summary Review on Different Theory Approaches. International Research Journal of Finance and Economics, (68), 7-13.

Rose, C. (2007). Can Institutional Investors Fix the Corporate Governance Problem? Some Danish Evidence. Journal of Management and Governance, 11(4), 405-428.

Shleifer, A., \& Vishny, R. W. (1997). A survey of corporate governance. The Journal of Finance, 52(2), 737-783. http://dx.doi.org/10.1111/j.1540-6261.1997.tb04820.x

Tian, J. J., \& Chung-Ming, L. (2001). Board composition, leadership structure and performance in Chinese shareholding companies. Asia Pacific Journal of Management, 18(2), 245-263. http://dx.doi.org/10.1023/A:1010628209918

Wallace, R. S. O., \& Naser, K. (1995). Firm-Specific Determinants of the Comprehensiveness of Mandatory Disclosure in the Corporate Annual Reports of Firms Listed on the Stock Exchange of Hong Kong. Journal of Accounting and Public Policy, 14(4), 311-368. http://dx.doi.org/10.1016/0278-4254(95)00042-9

Williams, R. J., Fadil, P. A., \& Armstrong, R. W. (2005). Top Management Team Tenure and Corporate Illegal Activity: The Moderating Influence of Board Size. Journal of Managerial Issues, 17(4), 479-493.

Xu, X., \& Wang, Y. (1999). Ownership Structure and Corporate Governance in Chinese Stock Companies. China Economic Review, 10(1), 75-98. http://dx.doi.org/10.1016/S1043-951X(99)00006-1 